

\section{DISCLAIMER}

This report was prepared as an account of work sponsored by an agency of the United States Government. Neither the United States Government nor any agency Thereof, nor any of their employees, makes any warranty, express or implied, or assumes any legal liability or responsibility for the accuracy, completeness, or usefulness of any information, apparatus, product, or process disclosed, or represents that its use would not infringe privately owned rights. Reference herein to any specific commercial product, process, or service by trade name, trademark, manufacturer, or otherwise does not necessarily constitute or imply its endorsement, recommendation, or favoring by the United States Government or any agency thereof. The views and opinions of authors expressed herein do not necessarily state or reflect those of the United States Government or any agency thereof. 


\section{DISCLAIMER}

Portions of this document may be illegible in electronic image products. Images are produced from the best available original document. 
Printed in the United States of America. Available from National Technical Informatinn Serviree

U.S. Department of Commerce

5285 Port Royal Road. Springfield, Virginia 22161

NTIS price codes-Printed Copy: A02; Microfiche A01

This report was prepared as an account of work sponsored by an agency of the United States Government. Neither the United States Government nor any agency thereof, nor any of their employees, makes any warranty, express or implied, or assumes any legal liability or responsibility for the accuracy, completeness, or usefulness of any information, apparatus, product, or process disclosed, or represents that its use would not infringe privately owned rights. Reference herein to any specific commercial product, process, or service by trade name, trademark, manufacturer, or otherwise, does not necessarily constitute or imply its endorsement, recommendation, or favoring by the United States Government or any agency thereof. The views and opinions of authors expressed herein do not nesesssarily state $\mathrm{nr}$ reflert thnşe of the United Statoe Govornmont or any agency thereot. 
ORNL/TM-7417

Dist. Category UC-12

Contract No. W-7405-eng-26

Engineering Technology Division

\section{ON THE TRACKING OF SMOKESTACK AND COOLING TOWER PLUMES USING WIND MEASUREMENTS AT DIFFERENT LEVELS}

R. L. Miller

A. A. N. Patrinos

Date Published - August 1980

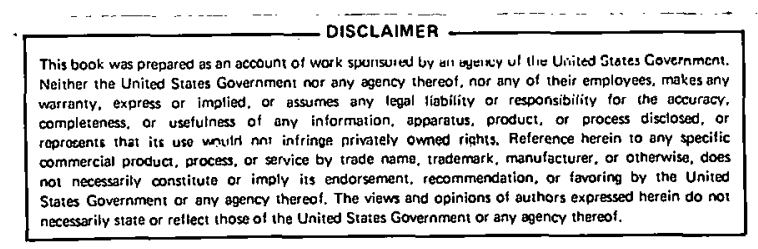

Prepared by the

OAK RIDGE NATIONAL LABORATORY

Oak Ridge, Tennessee 37830

operated by

UNION CARBIDE CORPORATION

for the

DEPARTMENT OF ENERGY 
THIS PAGE

WAS INTENTIONALLY

LEFT BLANK 


\section{Contents}

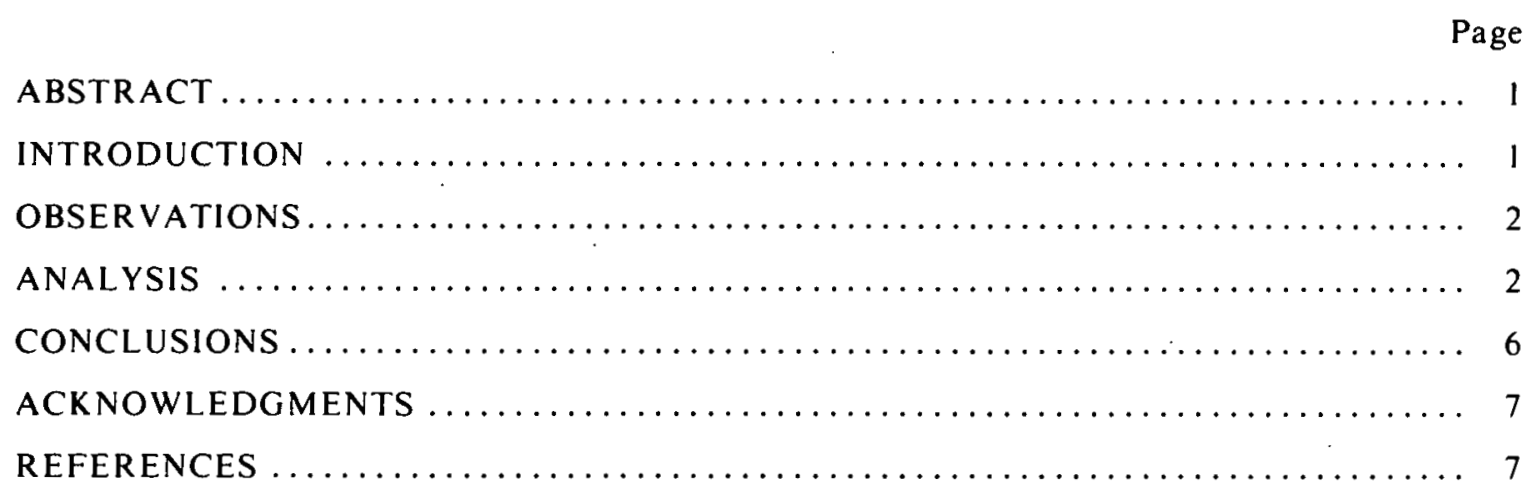




\title{
ON THE TRACKING OF SMOKESTACK AND COOLING TOWER PLUMES USING WIND MEASUREMENTS AT DIFFERENT LEVELS
}

\author{
R. L. Miller \\ A. A. N. Patrinos
}

\begin{abstract}
Relationships between cooling tower and smokestack plumes at the Bowen Electric Generating Plant in northwestern Georgia and wind direction measurements at levels from the surface to $850 \mathrm{mb}(\sim 1.5 \mathrm{~km})$ are examined. The wind measurements play an important role in estimating plume directions which in turn are utilized to establish control and target (upwind and downwind) areas for a study of plantinduced precipitation modification. Fifty-two plume observations were made during a three week period in December, 1979. Results indicate that a windset $(4.5 \mathrm{~km}$ from the plant) mounted at a level approximating that of the cooling tower plume is a better predictor of plume direction than surface windsets $(1.0 \mathrm{~km}$ from the plant $)$ or $850 \mathrm{mb}$ level winds. However, an apparent topographical influence on the wind direction measurements at the plume-level windset site somewhat limits its plume tracking capability, at least for ambient winds from the SW quadrant.
\end{abstract}

\section{INTRODUCTION}

The determination of the directions along which cooling tower and smokestack plumes from power plants travel is a major concern in studies using the upwind-downwind approach to investigate plant-induced weather modification. 'Approximation of plume directions is particularly complicated for studies requiring knowledge of the directions at given times rather than on a climatological basis. ${ }^{2}$ An approach to obtaining the desired data is by wind measurements at different levels; this is a challenging task.

In an effort tn estahlish the hest method for estimating plume directions from available wind measurements at the Bowen Electric Generating Plant (Plant Bowen) in northwestern Georgia, members of the Oak Ridge National Laboratory (ORNL) made observations of the cooling tower and smokestack plumes during a three week period in December 1979. The observations provided a comparison with wind data at levels from the surface to $850 \mathrm{mb}(\sim 1.5 \mathrm{~km})$ to determine the extent to which the wind directions at those levels reflected the plume directions. This investigation was part of a joint field study designated Winter Study of Power Plant Effects (WISPE) involving Battelle Pacific Northwest Laboratories, The Pennsylvania State University, and ORNL. The overall goal of WISPE was an improved understanding of the effects of cooling tower and smokestack plumes on local weather and atmospheric conditions. The field study was a part of the Meteorological Effects of Thermal Energy Releases (METER) program which is sponsored by the Department of Energy (DOE). ${ }^{3}$ Plant Bowen was selected as the site for WISPE because of its physical characteristics (the largest U.S. coal-fired power plant with cooling towers) and because it has been the target of extensive field studies. Since February 1978, ORNL has been operating a recording raingage and windset network around the 
plant to evaluate the potential precipitation modification by the heat and moisture releases. ${ }^{2}$ Plant Bowen, located about $64 \mathrm{~km}$ northwest of Atlanta and owned and operated by the Georgia Power Company, is a $3160 \mathrm{MW}$ (electric) plant with two smokestacks and four natural-draft cooling towers. The height of each smokestack is $305 \mathrm{~m}$, while the towers stand $119 \mathrm{~m}$ above the ground level of $220 \mathrm{~m}$ MSL.

The incorporation of the plume observations in WISPE addressed the problem of estimating the plume directions prior to and during storm events from available wind measurements. Knowledge of the approximate cooling tower plume direction is crucial to the ORNL study of potential precipitation modification; specifically, the statistical design employed in most analyses of the network rainfall data is based on the control-target (upwind-downwind) concept, resembling the designs of many cloud seeding experiments. ${ }^{4,5}$ Thus, given the wind directions near the surface and at $850 \mathrm{mb}$ for a particular storm event, can the plume directions be estimated satisfactorily?

Additionally, the wind measuremente and plume observations provided an cxcellent opportunity to examlne the infiluence of topography on wind direction. Previous investigations have found local topography to perturb both the direction and speed of the wind near the surface. ${ }^{6,7}$ The general topographical features in the study area have previously been described in detail; ${ }^{1}$ specific features at the windset sites are discussed in the following section.

\section{OBSERVATIONS}

Fifty-two observations of the cooling tower and smokestack plumes were made during the period Dec. 5-18, 1979; two morning and two afternoon observations were scheduled daily, regardless of atmospheric conditions, with additional observations taken during storms. The following items were recorded at each observation: date and time, description of sky, occurrence of precipitation, directions of cooling tower and smokestack plumes (based on a 16-point compass), estimated length and height of visible cooling tower plume, and additional remarks (plume bifurcation, strong shear, etc.). Note that the plume directions are taken to be the directions from which the winds are approaching, thereby corresponding with the wind measurements.

Simultaneous wind direction readings were obtained trom three recording windsets in the study area: two windsets located $1.0 \mathrm{~km} \mathrm{NNE}$ of Plant Bowen at a height of $6 \mathrm{~m}$ above ground level, and a meteorological station situated $4.5 \mathrm{~km}$ NE of the plant with wind instrumentation at the top of a $35-\mathrm{m}$. tower. The former two windsets, which are separated from each other by $\sim 50 \mathrm{~m}$, are sited in a flat, well-exposed area. The meteorological station. however, stands at the crest of a 120 -m hill in a large clearing which is surrounded by trees with heights of less than half of the tower. Additionally, the wind direction at the $850 \mathrm{mb}$ level was derived for each observation by interpolation of the National Weather Service maps.

\section{ANALYSIS}

The analysis of the data was directed toward the previously mentioned objectives of investigating the relationships between plume observations and wind measurements and studying the influence of topography on wind direction. Initially, a few fundamental stratifications were performed. Table I displays the wind direction distributions for observations and measurements. It should be noted that a comparison with climatological wind records would be of limited value, since the distributions contain a maximum of only 52 observations or measurements taken at varying intervals during the daylight hours; furthermore, care must be exercised in comparisons between distributions because of missing 
Table I. Wind direction distributions (number of occurrences)

\begin{tabular}{lcccccc}
\hline & $\begin{array}{c}\text { Surface } \\
\text { windset } \\
\text { No. 1 }\end{array}$ & $\begin{array}{c}\text { Surface } \\
\text { windset } \\
\text { No. 2 }\end{array}$ & $\begin{array}{c}\text { Meteorological } \\
\text { station }\end{array}$ & $\begin{array}{c}\text { Cooling } \\
\text { tower } \\
\text { plume }\end{array}$ & $\begin{array}{c}\text { Smokestack } \\
\text { plume }\end{array}$ & $\begin{array}{c}850 \mathrm{mb} \\
\text { level } \\
\text { winds }\end{array}$ \\
\hline N & 8 & 4 & 12 & 9 & 6 & 7 \\
NNE & 1 & 3 & 2 & 0 & 2 & 0 \\
NE & 1 & 1 & 0 & 0 & 0 & 0 \\
ENE & 2 & 2 & 0 & 1 & 0 & 0 \\
E & 3 & 3 & 3 & 1 & 2 & 0 \\
ESE & 7 & 3 & 1 & 4 & 4 & 0 \\
SE & 4 & 3 & 10 & 3 & 2 & 0 \\
SSE & 1 & 1 & 3 & 3 & 1 & 0 \\
S & 0 & 0 & 5 & 7 & 7 & 0 \\
SSW & 1 & 2 & 3 & 3 & 4 & 3 \\
SW & 2 & 1 & 0 & 3 & 5 & 6 \\
WSW & 0 & 1 & 2 & 3 & 0 & 12 \\
W & 1 & 1 & 1 & 0 & 2 & 6 \\
WNW & 4 & 5 & 2 & 2 & 3 & 9 \\
NW & 2 & 2 & 6 & 6 & 3 & 7 \\
NNW & 7 & 3 & 2 & 6 & 7 & 2 \\
Total & 44 & 35 & 52 & 51 & 48 & 52 \\
\hline
\end{tabular}

data which preclude a one-to-one correspondence. Nevertheless, several general results are noted. The majority of cooling tower and smokestack plumes traveled from the northern or southern sectors, with few occurrences from the east or west. Differences can be detected between the two plumes, but the overall pattern is quite similar (64\% of the observations matched identically). The surface windset measurements display prevailing winds in the northwestern and southeastern quadrants; the distributions would be almost identical because of the small separation distance, except that both windsets were inoperative at different periods of the field study due to power supply problems. The wind direction distribution at the meteorological station appears to be bracketed by the surface windset and plume distributions. Finally, the distribution of the winds at the $850 \mathrm{mb}$ level is markedly different from the others: there are no occurrences of winds with an easterly component. This finding suggests that the latter wind would be a poor predictor of plume direction.

Figure 1 presents a further analysis of the data by plotting the wind directions from all observations and measurements as a function of observation number. 'I his graphical display provides the opportunity for comparison of the wind directions at a set time, as well as following the trend from one observation to the next. The ordinate is displayed as several complete cycles of wind direction, thereby permitting a constant comparison of winds as they rotate around the compass. The wind at the $850 \mathrm{mb}$ level, however, has two breaks in its trace because it oscillates around the western sector rather than rotating around through the eastern sector. This is another indication that the $850 \mathrm{mb}$ wind level is inadequate as a predictor of plume direction. It appears that the meteorological station estimates the cooling tower plume considerably better than the two surface windsets. Indeed, for most observations the meteorological station is an acceptable predictor of the cooling tower plume (within $22.5^{\circ}$ for $88 \%$ of the observations).

An interesting feature of Figure 1 is the shifting back and forth of the six traces. The fluctuations tend to lessen with height, with the $850 \mathrm{mb}$ level wind being quite steady in comparison with the others. The traces are often aligned in an order corresponding to height, either following the familiar Ekman spiral model or some inverse of it. The meteorological station trace is frequently positioned between the 


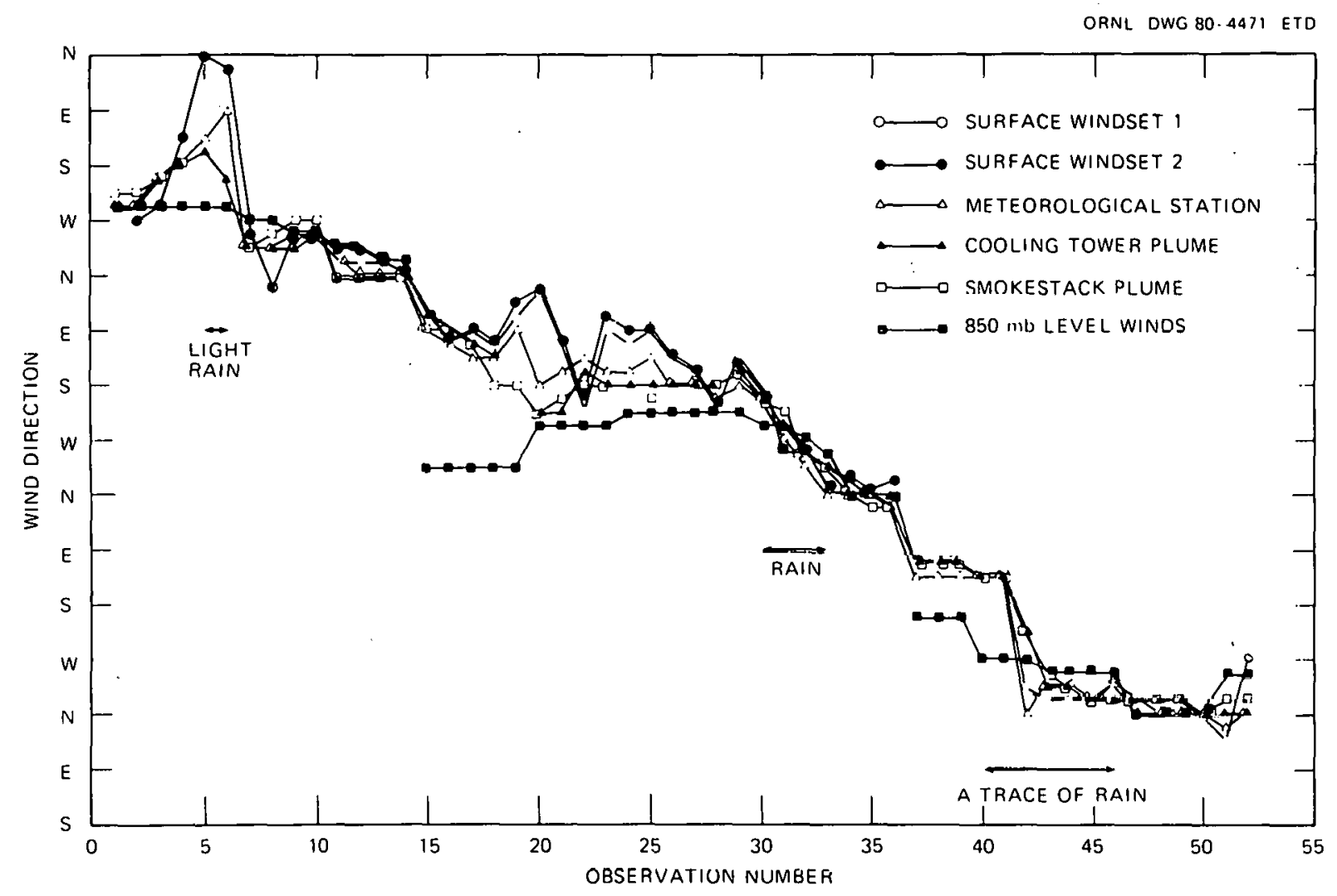

Fig. 1. Wind directions as a function of observation number. The ordinate is shown as several complete cycles to facilitate a continuous comparison between the winds.

surface windsets and the cooling tower plume, suggesting that its effective height also lies between the twn. In terms of absolute height, the windset at the meteorological station is $\sim 35 \mathrm{~m}$ above the mouth of the conoling tower: but since the elevation is greater at the former site and since plume rise should also be considered, the relative order of the wind direction traces is as expected. Only three periods of precipitation occurred during the field study, as denoted in Figure 1. I his was unfortunate since the objective of the observations was concerned primarily with wind relationships prior to and during storm events. The available data points are too few to draw any conclusions regarding relationships during storms.

Another analysis was performed by computing the correlation coefficicnts between five of the six wind directions. The $850 \mathrm{mb}$ level wind direction was subtracted from each of the three windset measurements and two plume observations to obtain five angulat differences for cach time of observation (providing none of the data were missing). This technique uf sacrificing onc sct of wind directions allows the remaining five sets to be readily correlated. The results are presented in Table II. The highest correlation is between the two surface windsets, and the lowest correlation involves the second surface windset and the cooling tower plume. The correlations indicate that the meteorological station with its higher coefficient is a better predict or of the cooling tower plume direction than the two surface windsets.

The previous results have shown that out of the available measurements, the meteorological station has best estimated the cooling tower plume direction. Concern has existed, however, regarding the topographical influence on the wind direction measured at the meteorological station beciuse it is 
Table II. Correlation coefficients between wind directions

\begin{tabular}{lccccc}
\hline & $\begin{array}{c}\text { Surface } \\
\text { windset } \\
\text { No. 1 }\end{array}$ & $\begin{array}{c}\text { Surface } \\
\text { windset } \\
\text { No. 2 }\end{array}$ & $\begin{array}{c}\text { Meteorological } \\
\text { station }\end{array}$ & $\begin{array}{c}\text { Cooling } \\
\text { tower } \\
\text { plume }\end{array}$ & $\begin{array}{c}\text { Smokestack } \\
\text { plume }\end{array}$ \\
\hline $\begin{array}{c}\text { Surface windset } \\
\text { No. 1 }\end{array}$ & 1.000 & 0.995 & 0.922 & 0.824 & 0.824 \\
$\begin{array}{c}\text { Surface windset } \\
\text { No. 2 } \\
\text { Meteorological } \\
\text { station }\end{array}$ & 1.000 & 0.906 & 0.769 & 0.797 \\
$\begin{array}{c}\text { Cooling tower } \\
\text { plume }\end{array}$ & & 1.000 & 0.906 & 0.906 \\
$\begin{array}{c}\text { Smokestack } \\
\text { plume }\end{array}$ & & & 1.000 & 0.979 \\
\hline
\end{tabular}

located on the crest of a 120-m hill. For this reason, a comparison was conducted between the meteorological station and the cooling tower plume by computing the difference between the two wind directions at a given time, $\theta_{\mathrm{MET}}-\theta_{\text {C.T. }}$ (where $\theta$ is in degrees of the compass), and stratifying each difference according to the cooling tower plume direction in which it occurred. This technique is quite similar to the method used by Weidner and Stearns. ${ }^{8}$ The differences were stratified by cooling tower plume direction since the plume was assumed to be uninfluenced by the topography. Figure 2 displays a graph of the mean differences, $\overline{\theta_{\mathrm{MET}}-\theta_{\mathrm{C} . \mathrm{T}}}$; note that because of the limited number of observations, some directions contain no points and others are based on one to nine observations. The only direction which appears somewhat out of line is SSW. The other graph depicted in Figure 2 is the mean absolute

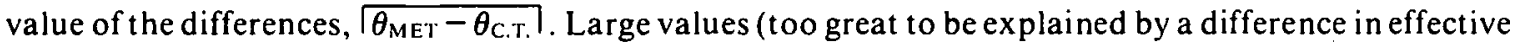
heights) occur in the SSW and SW directions, each the mean of three observations. A check of the absolute value of the differences, $\left|\theta_{\mathrm{MET}}-\theta_{\mathrm{C} . \mathrm{r} .}\right|$, , for all observations reveals six cases with magnitudes of $45^{\circ}$ or more: three with the cooling tower plume direction from the SW and one each from the directions of S, SSW, and NW.

Because of the sparsity of data, the differences were grouped together by quadrants; for example, the four cooling tower plume directions S, SSE, SE, and ESE were combined to form the SE quadrant. Table III presents for three quadrants (the NE quadrant contained only two observations) the calculations of $\overline{\theta_{\mathrm{MET}}-\theta_{\mathrm{C} . \mathrm{T}}}, \overline{\theta_{\mathrm{MET}}-\theta_{\mathrm{C} . \mathrm{T} .}}$, the standard deviation $\sigma_{\left(\theta_{\mathrm{MET}}-\theta_{\text {C.T. }}\right)}$, and the number of observations, $n$. The values of $\overline{\theta_{M E T}-\theta_{C r}}$ and $\sigma\left(\theta_{M E T}-\theta_{C_{i} r_{1}}\right)$, are substantially greater for the $\mathrm{SW}$ quadrant than the other quadrants. It should be noted, however, that $n$ of the $S W$ quadrant is about half of the other two.

Results of the comparison between the meteorological station and the cooling tower plume indicate signs of a topographical influence on the wind direction recorded by the former for cooling tower plume directions from the $\mathrm{SW}$ quadrant. It should be emphasized that due to the small number of observations, no definite conclusinns can presently be drawn; further observations are planned in an upcoming field study. Moreover, assuming a topographical effect is present for ambient southwesterly winds, a physical explanation is difficult if the other quadrants are not also affected because the hill is located in the SW corner of a "matrix" of other hills of similar height which would seem likely to influence wind direction at the meteorological station for ambient winds from other quadrants. At any rate, current speculation on the cause of a topographical effect is that the southwesterly flow is channeled through the small valleys to the north and east of the hill, and this shifting of flow in the valleys influences the flow at the crest of the hill. 


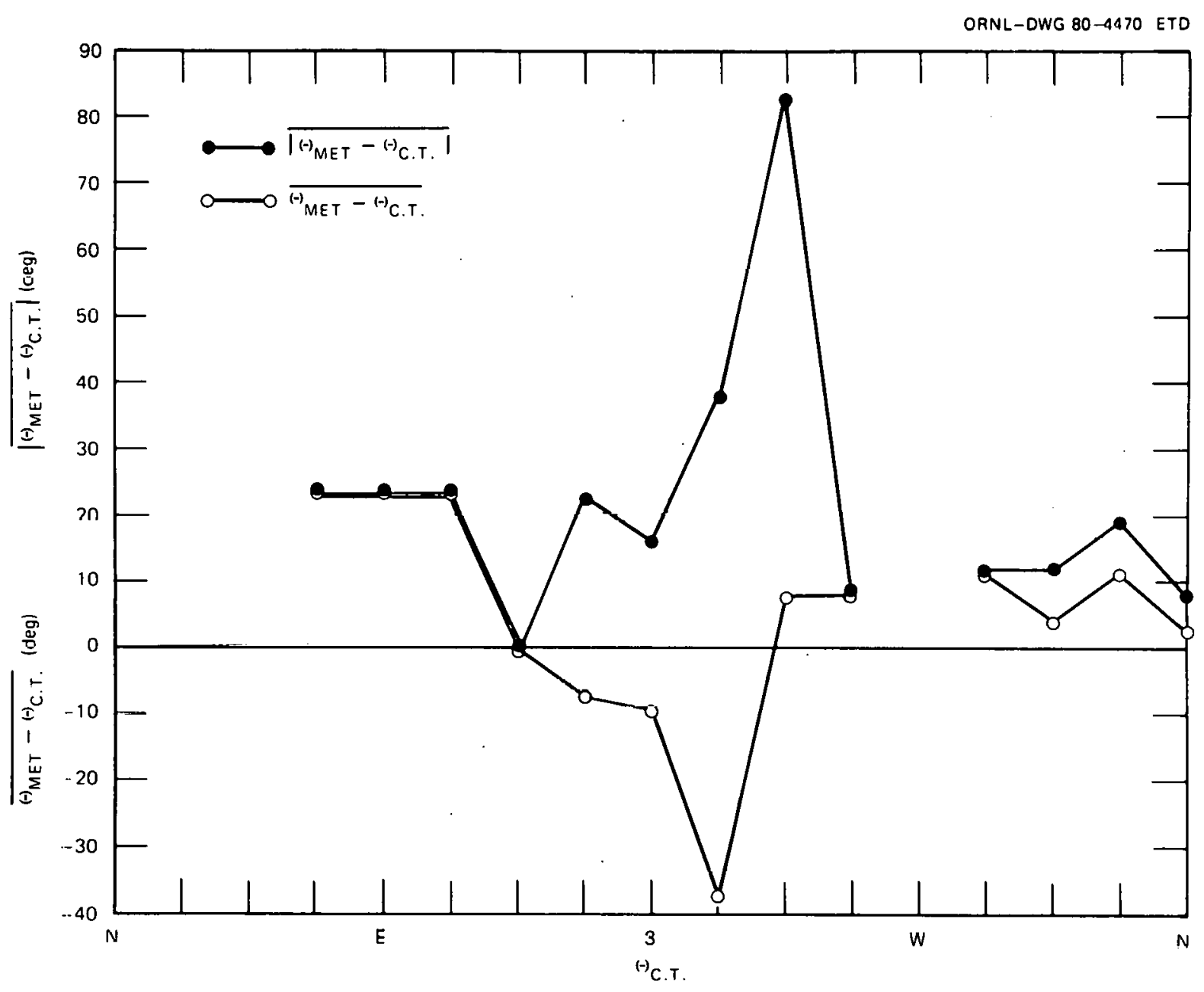

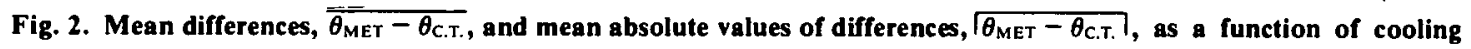
tower plume direction, $\theta_{\text {c.T. }}$.

Table III. Wind direction differences grouped by quadrants

\begin{tabular}{|c|c|c|c|c|}
\hline Quadrant & $\overline{\theta_{\mathrm{MET}}-\theta_{C, T_{i}}}$ & $\overline{\theta_{\mathrm{MRT}}-\theta_{r \mathrm{r}}}$ & $\sigma_{\left(\theta_{\text {iviet }}-\theta_{(.1 .)}\right.}$ & $"$ \\
\hline SE & 0.0 & 15.9 & 21.0 & 17 \\
\hline sW & $=7.3$ & 42.5 & 68.4 & 9 \\
\hline NW & 59 & 11.7 & 16.9 & 23 \\
\hline
\end{tabular}

\section{CONCLUSIONS}

Observations were made of the cooling tower and smokestark nlumes at Plant Bowen in northwestern Georgia for comparison with wind measurements at heights from the surface to $850 \mathrm{mb}$. This investigation was directed primarily toward determining the relationships between observations and measurements of wind direction prior to and during storm events. Based on the results of several analyses, the meteorological station was found to be a better predictor of the cooling tower plume 
direction than the surface windsets or $850 \mathrm{mb}$ level winds. A possible complication is an apparent topographical influence on the wind direction measurements of the meteorological station situated on top of a hill. The influence is only noticeable, at least from the available data, for cooling tower plume directions (assumed to be the ambient flow) from the $S W$ quadrant. Further observations planned for a future field study should answer existing questions concerning the best measurement or combination of measurements for plume directions prior to and during storm events and the extent of a topographical effect on the wind direction at the meteorological station.

\section{ACKNOWLEDGMENTS}

The preparation of this report was supported by the Department of Energy (Division of Advanced Nuclear Systems and Projects and Office of Health and Environmental Research) as part of the program on the Meteorological Effects of Thermal Energy Releases. The authors are indebted to Norbert Chen, Lincoln Jung, and Richard Saylor for their assistance in the data acquisition and to the Engineering Technology Division's Report Office for the professional graphic arts work.

\section{REFERENCES}

1. A. A. N. Patrinos, N. C. J. Chen, and R. L. Miller, "Spatial Correlations of Monthly Rainfall: Applications in Climatology and Weather Modification Experiments," J. Appl. Meteorol. 18, 719-732 (1979).

2. R. L. Miller, R. E. Saylor, and A. A. N. Patrinos, The METER-ORNL Precipitation Network: from Design to Data Analysis, OR NL/TM-6523, NTIS, Washington, D.C. (1978).

3. A. A. N. Patrinos and H. W. Hoffman, Meteorological Effects of Thermal Energy Releases (METER) Program Annual Progress Report for October 1977-September 1978, OR NL/TM-6867, NTIS, Washington, D.C. (1979).

4. P. A. P. Moran, "The Power of a Cross-over Test for the Artificial Stimulation of Rain," Austral. J. Statist. 1, 47-52 (1959).

5. P. W. Mielke, "Squared Rank Test Appropriate to Weather Modification Cross-over Design," Technometrics 16, 13-16 (1974).

6. L. L. Wendell, "Mesoscale Wind Fields and Transport Estimates Determined from a Network of Wind Towers," Monthly Weather Rev. 100, 565-578 (1972).

7. L. P. Steele, "A Study of the Relation between the Surface Wind at Trawsfynydd Power Station and Nearby Topography," Boundary-Layer Meteorol. 10, 381-392 (1976).

8. G. A. Weidner and C. R. Stearns, "Topographic Influence on Surface Winds," Boundary-Layer Meteorol. 14, 167-182 (1978). 


\section{THIS PAGE}

WAS INTENTIONALLY

LEFT BLANK 


\section{Internal Distribution}

I. S. I. Auerbach

2. H. F. Bauman

3. N. C. J. Chen

4. W. B. Cottrell

5. C. C. Coutant

6. D. M. Eissenberg

7. H. L. Falkenberry

8. M. H. Fontana

9. H. W. Hoffman

10. L. Jung

11. F. C. Kornegay

12. S. E. Lindberg

13. H. A. McLain

14. C. W. Miller

15-19. R. L. Miller
20-24. A. A. N. Patrinos

25. M. W. Rosenthal

26. T. H. Row

27. R. E. Saylor

28. I. Spiewak

29. H. E. Trammell

30. D. B. Trauger

31. A. J. Witten

32. ORNL Patent Office

33. Central Research Library

34. Document Reference Section

35-36. Laboratory Records Department

37. Laboratory Records (RC)

38. Nuclear Safety Information Center

39. EISO Library

\section{External Distribution}

40. D. S. Ballentine, Office of Health and Environmental Research, U.S. Department of Energy, Washington, DC 20545

41. J. H. Coleman, Air Quality Branch, Tennessee Valley Authority, River Oaks Building, Muscle Shoals, AL 35660

42. R. A. Dirks, National Science Foundation, 1800 G Street, Northwest, Washington, DC 20550

43. R. L. Drake, Battelle Pacific Northwest Laboratories, Battelle Boulevard, Richland, WA 99352

44. J. F. Fairobent, Office of Nuclear Reactor Regulation, U.S. Nuclear Regulat ory Commission, Washington, DC 20555

45. C. H. Goodman, Southern Company Services, Inc., P.O. 2625, Birmingham, AL 35202

46. C. Hakkarinen, Electric Power Research Institute, P.O. Box 10412, Palo Alto, CA 94303

47. S. R. Hanna, Atmospheric Turbulence Diffusion Laboratory, NOAA, Oak Ridge, TN 37830

48. B. B. Hicks, Argonne National Laboratory, 9700 South Cass Avenue, Argonne, IL 60439

49. P. Hobbs, Department of Atmospheric Sciences, University of Washington, Seattle, WA 98195

50. J. Jansen, Electric Power Research Institute, P.O. Box 10412, Palo Alto, CA 94303

51. A. L. Kistler, Department of Mechanical Engineering and Astronautical Sciences, Northwestern University, Evanston, IL 60201

52. L. R. Koenig, Rand Corporation, 1700 Main Street, Santa Monica, CA 90406

53. R. Kornasiewicz, Office of Standards Development, U.S. Nuclear Regulatory Commission, Washington, DC 20555

54. H. E. Landsberg, Department of Meteorology, University of Maryland, College Park, MD 20742

55. H. Moses, Office of Health and Environmental Research, Department of Energy, Washington, DC 20545

56. J. H. Motz, Georgia Power Company, P.O. Box 4545, Atlanta, GA 30302

57. C. J. Nappo, Atmospheric Turbulence Diffusion Laboratory, NOAA, Oak Ridge, TN 37830 
58. R. S. Nietubicz, Chalk Point Cooling Tower Project, c/o Bureau of Air Quality and Noise Control, O'Conor Building, 201 West Preston Street, Baltimore, MD 21201

59. Y. Onishi, Battelle Pacific Northwest.Laboratories, Battelle Boulevard, Richland, WA 99352

60. H. D. Orville, Institute of Atmospheric Sciences, South Dakota School of Mines and Technology, Rapid City, SD 57701

61. T. J. Overcamp, Environmental Systems Engineering, Clemson University, Clemson, SC 29631

62. R. Pena, Department of Meteorology, The Pennsylvania State University, University Park, PA 16802

63. R. Perhac, Electric Power Research Institute, P.O. Box 10412, Palo Alto, CA 94303

64. A. J. Policastro, Argonne National Laboratory, 9700 South Cass Avenue, Argonne, IL 60439

65-67. A. Rubin, Advanced Nuclear Systems and Projects Division, Department of Energy, Washington, DC 20545

68. E. Ryzner, Department of Atmospheric and Oceanic Science, University of Michigan, Ann Arbor, MI 48109

69-71. W. F. Savage, Adyanced Nuclear Systems and Projects Divisinn, Department of Fnergy, Washington, DC 20545

72. G. L. Sherwood, Advaneed Nuelear Systemins and Piviects Division, Department of Energy. Washington, DC 20545

73. D. H. Slade, Office of Health and Environmental Research. Department of Fnergy. Washington, DC 20545

74. P. Slawson, Department of Mechanical Engineering, University of Waterloo, Waterloo. Ontario, Canada

75. W. G. N. Slinn, Atmospheric Sciences Department, Oregon State University, Corvallis, . OR 97331

76. S. Strauch, Advanced Nuclear Systems and Projects Division, Department of Energy, Washington, DC 20545

II. D. W. I homson, Department of Meteorology, The Pennsylvania State University, University Park, PA 16802

78. J. L. Vogel, Illinois State Water Survey, Box 232, Urbana, IL 61801

79. L. Winiarski, Environmental Protection Agency, 200 South 35th Street, Corvallis, OR 97330

80. Office of Assistant Manager for Energy Research and Development, Department of Energy, Box F., Oak Ridgr., TN 378,30

81. Director, Reactor Division, Department of Energy, Box E, Oak Ridge, TN 37830

82-349. Given distribution as shown in DOE/TIC-4500 under category UC-12 